\title{
PRINT ISLAM: MASS MEDIA AND IDEOLOGICAL RIVALRIES AMONG INDONESIAN MUSLIMS
}

\section{Robert W. Hefner}

On December 30, 1996, a few dozen protesters gathered to demonstrate outside the offices of Indonesia's leading Islamic newspaper, Republika, in the southern suburbs of the capital city of Jakarta. ${ }^{1}$ The protesters were from a coalition of some eighteen Muslim organizations, all with spiritual ties to the Dewan Dakwah Islamiyah Indonesia (Indonesian Counsel for Islamic Predication, or DDII), one of Indonesia's leading organizations for reformist Islam. On this occasion there was little of the tension characteristic of the group's earlier protests against the Muslim daily. Some months earlier, on April 17, 1995, the protest had become so heated that newspaper staff feared the demonstrators might ransack the building (a charge that the DDII leaders dismiss as ludicrous). ${ }^{2}$ This time the demonstrators were careful and orderly, behaving as if they were playing parts in a scripted affair. They carried banners and chanted slogans, and presented Republika officials with letters of protest detailing their objections to the Muslim daily's coverage. They also carried copies of the articles they viewed as having offended the Muslim community, and photocopies of letters sent earlier in the month by leading reformist personalities (most, again, with cordial ties to the DDII) expressing similar outrage at Republika's reporting.

By the standards of Indonesian politics during 1996, the demonstration this bright December morn was a tame affair. After all, this was a year that had begun with the government-engineered overthrow of the popular leader of the Indonesian Democratic

\footnotetext{
${ }^{1}$ I would like to thank John Bowen, Jeroen Peeters, and Dale F. Eickelman for comments on this paper, an earlier version of which was presented at the conference, "Mass Media and the Transformation of Islamic Discourse," International Institute for Asian Studies, Leiden, March 24, 1997.

2 Interviews with Republika reporters, June 11, 1995.
} 
Party (PDI), Megawati Soekarnoputri, the daughter of Indonesia's first president, Soekarno. Megawati ran afoul of government officials when her rising popularity began to raise doubts about the ability of the ruling party, Golkar, to win the 1997 elections in the populous provinces of East and Central Java. Secret polls commissioned by Golkar strategists in early 1995 indicated that the party was running behind Megawati's Democratic Party in East Java, and was in serious trouble in Central Java as well. ${ }^{3}$ Party strategists were thus instructed to come up with a plan to oust Megawati. In early 1996 they arranged for a special convention of the Democratic Party at which a new, pro-government leader was elected; the outcome was a foregone conclusion because Megawati's followers were excluded from the event. Over the next few months, Megawati's supporters continued to mount effective resistance against her government-installed replacement, maintaining control of many of the PDI's regional branches and its national headquarters in Jakarta. Irritated by this standoff, on July 27 the government-backed PDI faction, supported by security officials and street thugs (preman) hired for the occasion, attacked the PDI's Jakarta headquarters where Megawati supporters had continued to hold rallies and give speeches. Three people died in the attack, and more than twenty were officially listed as "disappeared." Over the next two days, Jakarta was shaken by its worst political riots in more than twenty years, as thousands of angry PDI supporters, joined by residents of Jakarta's slums, took to the streets, ransacking government offices and setting fire to businesses owned by people with ties to the regime.

Over the next few months, Megawati supporters kept up a campaign of nonviolent resistance against the new party leadership. In the short term, however, the government stratagem seemed to have succeeded, though at an unexpectedly high cost to the Soeharto regime's international image. Through a series of arrests and press campaigns, the government also took advantage of the opportunity to crack down on left-leaning elements of the pro-democracy and labor movements, both of whom had rallied to the Megawati cause. In the words of one of Indonesia's most respected human-rights lawyers, Adnan Buyung Nasution, these shocking events left Indonesia's small pro-democracy movement thoroughly "disoriented" and "without any idea as to what to do next." 4

This was not the only violence in 1996 . In a country internationally renowned for its many courageous advocates of Muslim tolerance, 1996 had seen the worst incidents of putatively "anti-Christian" violence in the fifty-year history of the Indonesian Republic. There had been scattered church burnings in 1994, but few people were prepared for the enormity of violence that began in the middle of 1995 and intensified throughout 1996. All together, in an eighteen month period, some two hundred Christian churches were damaged or destroyed..$^{5}$ The worst of these incidents took

\footnotetext{
3 Anonymous interview with Golkar official on June 17, 1995.

4 Interview, January 4, 1997. Nasution also observed that he felt the prodemocracy movement had erred in placing all of its hopes on the PDI as the locomotive of democratic reform. He argued that democratization had to be pursued on several fronts, including legal and electoral. He regretted that some of Megawati's younger supporters had unrealistically believed that everything could be changed at once. In the aftermath of the July 27 affair and in the run-up to a post-Soeharto era, he felt that it was important to dialogue with people from varied backgrounds, including government and military officials.

5 Not all of the violence, it should be emphasized, featured "Muslims" against "Christians." In the troubled province of East Timor, residents protesting continuing military repression in their province
} 
place in 1996 in the cities of Surabaya, Situbondo, and Tasikmalaya on the island of Java. In each of these cases, small incidents-which typically did not pit Muslims against Christians, but instead involved local Muslims clashing with police or civil authorities-then escalated into large-scale violence aimed at government officials, wealthy Chinese, and Christians.

The scope and intensity of the violence, and the surprising inability of state authorities to contain it, caused much soul-searching among Muslim intellectuals, many of whom have long taken justifiable pride in modern Indonesia's record of multireligious tolerance. Among journalists and politicians, however, the riots gave rise to charges and countercharges that the violence was in fact engineered by a third party. Officials sympathetic to the government-sponsored Association of Indonesian Muslim Intellectuals (ICMI) insisted that the culprits had nothing to do with the Muslim community but were underground remnants of the Indonesian Communist Party (PKI). Authorities hostile to ICMI, however, typically offered a different explanation, arguing that the violence was the work not of the communist underground but of extremist hardliners in the Muslim community. Though radically different in their conclusions, these interpretations agreed in seeing the violence as not merely an expression of "anti-Christian" sentiment, but of behind-the-scenes power struggles.

It is this larger background that made the demonstration outside the Republika offices so interesting. Whereas earlier demonstrations had faulted the newspaper for reporting on "un-Islamic" entertainments (such as Indonesian soap operas, Western films, and modern dance troupes) and for its "tendency to adopt a cosmopolitan attitude," 6 the December demonstration condemned the Republika staff for their biased, "left-leaning" (kiri-kirian) coverage of the PDI violence and recent urban riots. In what follows, I want to describe these grievances, and the differences of ethical and political vision to which they testify. Having elsewhere discussed ICMI, the organization to which Republika is linked, ${ }^{7}$ my primary focus in the following discussion will be on the Dakwah Council or DDII. In many respects studying the interactions between this organization and the Soeharto government provides the best illustration of the scale and ambiguity of the government's shift in attitude toward the Muslim community. It also illustrates the as yet uncertain outcome of that evolution.

From a comparative perspective, finally, this Indonesian example illustrates the centrality of print media in the struggle for public opinion in the Muslim world, and the obstacles to developing an open and pluralistic "public sphere" in situations of

went on a rampage against Muslim immigrants, whom they claimed were being recruited to the region so as to change its ethnic and religious balance. Muslim mosques and shops were burned, provoking outrage among Indonesian Muslims and causing some Islamic leaders to accuse the human rights community of a double-standard when it came to protecting the rights of Muslims.

6 See, for example, the text of the April 1995 "Letter of Concern," reprinted in Media Dakwah, No. 271 (January 1997): 19-20.

${ }^{7}$ See Robert W. Hefner, "Islam and Democratization in Indonesia," in R. Hefner and Patricia Horvatich, Islam in an Era of Nation States: Politics and Religious Renewal in Muslim Southeast Asia (Honolulu: University of Hawaii Press, 1997), pp. 75-127. 
authoritarian control. ${ }^{8}$ In Indonesia and other majority-Muslim societies, the expansion of mass education in the aftermath of the Second World War played an important role in facilitating the establishment of new Muslim print media. Mass education created a public eager to consume Islamic works and open to new perspectives on politics and society. These developments also created conditions for the ascent of a new category of religious leader, different in worldview and political commitment from the carefully trained scholars (ulama) of traditional Islam. ${ }^{9}$ As Dale F. Eickelman and James Piscatori have highlighted in their recent Muslim Politics, these events combined to fragment religious authority among Muslims, unleashing "competition and contest over both the interpretation of symbols and control of the institutions, formal and informal, that produce and sustain them."10

Few institutions are of more critical importance in this contest of meanings than the varied print media through which Muslims disseminate and debate alternative visions of Islam and nation. In Indonesia, the dispute between the DDII and Republika provides an unusually clear prism through which to assess such ideological divides and the competing religious authorities of which they are part. The conflict also says much about the manner in which these divisions are being drawn into a high-stakes struggle over the role of Islam in a post-Soeharto era.

\section{The DDII and the Modernist Travail}

Sometimes portrayed by Western analysts as a "fundamentalist" organization, the Indonesian Council for Islamic Predication (DDII) is, in fact, an umbrella association of reformist Muslims with varied temperaments and political ideals. ${ }^{11}$ Beyond their

\footnotetext{
8 Though I do not develop its theoretical terms in this essay, the concept of "public sphere" to which I refer involves a sphere of open and unconstrained communication outside of the state (and thus in "civil society"), in which citizens exchange and debate ideas relevant to civil life and government. Much of the literature on the public sphere originated in discussions inspired by Jurgen Habermas's rather idealized account of the sphere's development in Western Europe, as presented in his The Structural Transformation of the Public Sphere: An Inquiry into a Category of Bourgeois Society, trans. Thomas Burger (Cambridge: MTT Press, 1991). See especially Craig Calhoun, ed., Habermas and the Public Sphere (Cambridge: MIT Press, 1993); and Jean L. Cohen and Andrew Arato, Civil Society and Political Theory (Cambridge: MIT Press, 1992). For a highly critical discussion of the concept in an Islamic context, see Talal Asad, "The Limits of Religious Criticism in the Middle East: Notes on Islamic Public Argument," in Asad, Genealogies of Religion: Discipline and Reasons of Power in Christianity and Islam (Baltimore and London: Johns Hopkins University Press, 1993), pp. 200-236.

${ }^{9}$ On the influence of mass education on religious authority in Islam, see Olivier Roy, "The Islamist New Intellectuals," in The Failure of Political Islam, trans. Carol Volk (Cambridge: Harvard University Press, 1994), pp. 89-106; and Dale F. Eickelman and Jon W. Anderson, "Print, Islam, and the Prospects for Civic Pluralism: New Religious Writings and Their Audiences," Journal of Islamic Studies 8,1 (1997): 43-62.

${ }^{10}$ Dale F. Eickelman and James Piscatori, Muslim Politics (Princeton: Princeton University Press, 1996), p. 5; see also, Dale F. Eickelman, "Mass Education and the Religious Imagination in Contemporary Arab Societies," in American Ethnologist 19,4 (November 1992): 643-655. For an Egyptian illustration of massculture construction, see Walter Armbrust, Mass Culture and Modernism in Egypt (Cambridge: Cambridge University Press, 1996).

11 The charge of "fundamentalism" is a recurring theme in R. William Liddle's interesting, but analytically unmeasured, polemic against the DDII, "Media Dakwah Scripturalism: One Form of Islamic Political Thought and Action in New Order Indonesia," in Mark R. Woodward, Toward a New Paradigm: Recent Developments in Indonesian Islamic Thought (Tempe: Arizona State University, 1996), pp. 323-56.

Generalizations like "fundamentalist" or "scripturalist" obscure the diverse ideologies and temperaments
} 
commitment to a particular understanding of Islam, what DDII supporters have in common is, first and foremost, allegiance to the memory of Indonesia's largest Muslim reformist political party, Masyumi, and to, more particularly, that faction of the party associated with its most famous leader, Mohammad Natsir. ${ }^{12}$ It was under Natsir's direction that the DDII was founded in 1967 by Muslim scholars and politicians linked to Masyumi.

During Indonesia's brief period of parliamentary democracy (1950-57), Masyumi had been the largest of several Islamic parties, and, in the 1955 elections, the second largest of the political parties in the nation as a whole. Though in Java (where almost two-thirds of Indonesia's population resides) the Nationalist and Communist Parties enjoyed a larger following, on Indonesia's outer islands Masyumi was the most broadly based political organization. The Masyumi leader, Mohammad Natsir, had served as Minister of Information in the republican government and as first Prime Minister after independence; his party also played an honorable role in several of the country's early coalition governments. ${ }^{13}$ In the late 1950s, however, as President Soekarno stumbled toward heightened collaboration with the Communist Party (in part to counterbalance the growing power of the military), Masyumi leaders became increasingly critical of the president's authoritarian rule. They shared this view and a commitment to constitutional government with the much smaller but intellectually influential party of the social-democratic left, the Socialist Party (PSI).

During 1958-1959, military and civilian authorities in several provinces rebelled against the central government, demanding a devolution of powers to the provinces and limits on Soekarno's power. ${ }^{14}$ Acting as individuals not party representatives,

of rank-and-file members of organizations like the DDII. The great majority of senior DDII supporters align themselves with the organization out of a sense of allegiance to the Natsir faction of Masyumi, which they regard as having been constitutionally minded, loyal to the republic, and unfairly persecuted. Many of the organization's members are political moderates, though their theological center of gravity tends toward a conservative varient of reformism. In deference to Liddle's position, however, it must also be acknowledged that the dynamics of reformist politics have changed since the Masyumi era, and, as I note later, a faction within the organization has hardened its attitudes on constitutional democracy, religious pluralism, and the West. With its shocking caricature of Liddle behind a Star of David, the published reaction of some Media Dakwah writers to Liddle's article (which was published in translation in Indonesia) provides one especially unhappy illustration of just such a hardening. See "Menjawab Liddle" (To Answer Liddle), Media Dakwah, No. 230 (August 1993): 41-58.

12 On Natsir's background and career, see Yusril Thza, "Combining Activism and Intellectualism: The Biography of Mohammad Natsir," Studia Islamika 2,1 (1995): 111-47, and Howard M. Federspiel, Persatuan Islam: Islamic Reform in Twentieth Century Indonesia (Ithaca: Cornell Modern Indonesia Project, 1970) Federspiel notes that, before Masyumi's founding, Natsir had been a leading figure in the theologically conservative reformist organization Persatuan Islam (Persis). The uncompromising writing style I describe below for Media Dakwah was also a characteristic of Persis. Rather than being identified with the Masyumi legacy as a whole, then, the DDII's genealogy may in certain respects owe more to the Persis faction in Masyumi.

13 See Herbert Feith, The Decline of Constitutional Democracy in Indonesia (Ithaca and London: Cornell University Press, 1962), pp. 146-176.

14 On the party rivalries and national struggles that formed the background to the rebellions, see Daniel $S$. Lev, The Transition to Guided Democracy: Indonesian Politics, 1957-1959 (Ithaca: Cornell Modern Indonesia Project, 1966), especially pp. 11-132; and Deliar Noer, Partai Islam di Pentas Nasional (Jakarta: Grafiti Pers, 1987), pp. 369-388. For a DDII view of these events, see Lukman Hakiem's biography of Anwar Harjono, Perjalanan Mencari Keadilan dan Persatuan (Jakarta: Media Dakwah, 1993), pp. 203-212. 
several Masyumi leaders, including Natsir, went over to the rebel side. ${ }^{15}$ Officially the party leadership refused to support the rebellion, urging a negotiated settlement; however the leadership also rejected Soekarno and the military's demands that they condemn the rebellion outright. Sensing an opportunity to strike at two of his most effective critics, Soekarno took advantage of the crisis to ban Masyumi and the Socialist Party. Months later (in January 1962), as the final remnants of the rebellion were being mopped up, the president also imprisoned much of the leadership of the two parties, including Natsir. As these two parties had been outspoken proponents of the rule of law and democratic proceduralism, the elimination of Masyumi and PSI dealt another blow to Indonesian democracy and represented one more step in a continuing shift of power from society to the state. ${ }^{16}$

A few years later, of course, Soekarno himself fell from power, and it looked for a while as if Masyumi's political fortunes might be restored. In the aftermath of a failed left-wing officers' coup on September 30, 1965, Masyumi supporters and other Muslim groupings, along with the conservative wing of the nationalist party, joined forces with the Indonesian armed forces to undercut Soekarno's power. During late 1965 and early 1966, this unwieldy alliance also mounted a fierce campaign against the Communist Party, liquidating its cadres and eliminating it forever as a serious political force. Despite the party's support for this campaign, the imprisoned Masyumi leaders were not freed until mid-1966. By late 1966, it was becoming clear that, though the government might tolerate the formation of a reformist political party, it was not about to allow Masyumi's rehabilitation or allow its leaders opportunities to play prominent roles in a new Islamic party. This was but the beginning of a long winter of discontent for reformist Muslims faithful to the Masyumi vision. For the next twenty years New Order leaders blocked all efforts to reconstitute Masyumi as a national party; only in the early 1990s were party leaders invited by the government to rejoin the national dialogue, albeit even then on strictly circumscribed terms.

These, then, were the circumstances in which Natsir and other Masyumi leaders invited preachers, teachers, and political leaders to meet in February of 1967 in the Tanah Abang region of Central Jakarta to discuss the formation of a new Dakwah Counsel. The organization was formally launched three months later, on May 9, 1967. From the beginning, DDII leaders made no attempt to hide their belief that dakwah (predication, affirmation of the faith) is a political as well as religious activity, and theirs was to be a political and religious organization. In a 1991 interview with a Muslim researcher, Natsir recalled his motives for founding the DDII in just such terms: "We are no longer conducting dakwah by means of politics, but engaging in political activities by means of dakwah. The result will be the same."17 More particularly, in the tightly controlled circumstances of the early New Order, the DDII leadership hoped that religious predication might create an atmosphere more conducive to the realization of Islamic political values. In strong contrast to some of

\footnotetext{
15 See Federspiel, Persatuan Islam, p. 184.

16 On the changing nature of state-society relations in Indonesia, see Benedict R. O'G. Anderson, "Old State, New Society: Indonesia's New Order in Comparative Historical Perspective," Journal of Asian Studies 42 (May 1983): 477-96; and Herbert Feith, The Decline, pp. 578-608.

17 Cited in Thza, "Combining Activism and Intellectualism," p. 129.
} 
their theologically liberal rivals, DDII spokespeople insist that, in Islam, the linkage between religion and politics must not merely be moral, but direct and systematic.

The idea that religion cannot be separated from politics is, of course, a familiar claim in Islamist discourse and can be interpreted in quite different ways, including liberal or civil democratic ones. ${ }^{18}$ In reflecting on its meaning here in Indonesia, it is important not to assume that the DDII was merely using religion to promote what were otherwise non-religious ends. On the contrary, one of the DDII's primary aims was to respond to what they and many other Muslims regarded as a religious calamity of enormous proportions. ${ }^{19}$ The event they had in mind was the movement of large numbers of nominally Islamic Javanese into Hinduism, syncretic mysticism, and, most significantly, Christianity. In the chaotic aftermath of the killings during 1965-1966, no one was certain as to how many nominal Javanese were leaving Islam. However, the triumphalist declarations of a few Christian missionaries (many supported by American Protestant missions) implied that the movement into Christian ranks was massive; a few foreigners spoke dizzily of winning the majority of Javanese to Christianity in a twenty year period. ${ }^{20}$ In historical retrospect, it is clear that, while conversion to Christianity increased dramatically in the late 1960 s and 1970 sinvolving upwards of one and a half million people (about 1.5 to 2 percent of the Indonesian population at that time)-it was nowhere near the scale feared by conservative Muslims or forecast by foreign missionaries. ${ }^{21}$ Under the turbulent circumstances of the early New Order, however, it was impossible to gauge this fact with confidence. What was clear was that many of the converts came from what had been communist strongholds in East and Central Java, a fact that only heightened Muslim anxieties as to the potential scale of conversion.

Though secular nationalists were also represented in their ranks, many of the converts came from communities ravaged by the anticommunist killings of 1965-1966. Between one quarter and one-half million people had died at that time, and another two million had been imprisoned.22 Many more lived in the shadow of violence, uncertain whether they too might fall victim to another anticommunist onslaught.

18 See, for example, the discussion of competing understandings of this point in John L. Esposito and John O. Voll, Islam and Democracy (New York: Oxford University Press, 1996), pp. 4-6.

${ }^{19}$ It should be noted, however, that Christian efforts to convert Muslims in Indonesia had long been an issue of concern to leaders like Natsir, as well as the Persatuan Islam of which he was part. See, for example, the essays collected in his Islam dan Kristen di Indonesia (Jakarta: Media Dakwah, 1969), several of which date from the colonial era; see also Federspiel, Persatuan Islam, p. 180.

20. See for example some of the missionary commentaries quoted in Avery T. Willis, The Indonesian Revival Why Two Million Came To Christ (Pasadena: William Carey Library, 1977).

21 This is not to deny that, from a Muslim perspective, the conversion was not a significant event. Much of the conversion took place in urban areas, and in some of Central Java's largest cities the number of Christians grew from 1-2 percent prior to 1965 to more than 10 percent.

22 The two most comprehensive studies of the violence are the collection edited by Robert Cribb entitled The Indonesian Killings 1965-1966: Studies from Java and Bali (Clayton, Victoria [Australia]: Monash Papers on Southeast Asia, No. 21, Centre of Southeast Asian Studies, Monash University, 1990), and, for Bali, Geoffrey Robinson's The Dark Side of Paradise: Political Violence in Bali (Ithaca and London: Cornell University Press, 1995). For an East Java case study of the killings, see my, The Political Economy of Mountain Java: An Interpretive History (Berkeley and London: University of California Press, 1993), Chapter 11. 
Earlier, in the 1950s, a small number of people in the nominally Islamic or "Javanist" community had flirted with conversion from Islam to Christianity or Javanese mysticism, but none of these initiatives had turned into genuine mass movements. ${ }^{23}$ In the aftermath of 1965-1966, however, pressures increased on all citizens to profess an officially sanctioned religion, and Javanese mysticism was not among the options allowed. Stung by the political violence and convinced that Muslim organizations had sanctioned the killings, a few Javanists now seemed prepared to renounce Islam altogether.

This threat of large-scale diversion from Islam was one of the key issues to which the DDII sought to respond. As a reformist organization that had inherited an educated and disciplined cadre from Masyumi, the DDII hoped to bring to the challenge educational and "scientific" skills lacking in other dakwah organizations. The DDII's leadership identified four tasks as critical to its endeavor: 1) the training of skilled preachers; 2 ) the publication of the written materials required for a more effective and ideologically informed predication; 3) the deployment of dakwah preachers to regions identified as vulnerable to non-Islamic proselytization (especially Christian); and 4) analysis of the cultural and organizational requisites of dakwah consolidation in regions visited by predication teams.

In focusing on these goals, the DDII sought to distinguish its specializations from existing dakwah organizations, such as, most notably, the fifty-year old grande dame of modernist organizations, Muhammadiyah. Though some DDII leaders were also members of that organization, historically the Muhammadiyah had sought to emphasize educational and social-welfare programs, downplaying-though never entirely ignoring-direct political action. ${ }^{24}$ By contrast with Muhammadiyah, the DDII's founders were openly and incessantly preoccupied with governmental policies that affected the Muslim community. In other words, the DDII's chosen specialization in the dakwah field was religious politics, concerned with matters ranging from national religious policy to local officials' attitudes toward predication. In this sense the DDII perpetuated the politicized understanding of predication developed by Masyumi during the heated struggles of the 1950s, when religious education had been drawn into the campaign against communists and secular nationalists. In a 1978 interview, Mohammad Natsir likened the DDII to a little electrical generator located behind and beneath a house, so that its noise could not be heard even as it lights up the whole house. ${ }^{25}$ This was not a predication for private piety alone.

${ }^{23}$ For examples of diversion from Islam, see Clifford Geertz's "Ritual and Social Change: A Javanese Example," in Geertz, The Interpretation of Cultures (New York: Basic Books, 1973), pp. 242-69, and my discussion of Javanese Buddha-Visnu Religion, in "The Political Economy of Islamic Conversion in Modern East Java," in William R. Roff, ed., Islam and the Political Economy of Meaning: Comparative Studies of Muslim Discourse (London: Croom Helm, 1987), pp. 53-78.

24 See M. Sirajuddin Syamsuddin, "Religion and Politics in Islam: The Case of Muhammadiyah in Indonesia's New Order," PhD Dissertation, Program in Islamic Studies, University of California Los Angeles, 1991.

${ }^{25}$ Cited in Lukman Hakiem's brief but illuminating history of the Dewan Dakwah, "Tiga Windu Dewan Dakwah, Mesin Diesel yang Menghidupkan" (A Quarter Centry of Dewan Dakwah, A Diesel That Brings to Life], in Media Dakwah (March 1991): 33-40. 
The DDII's interest in extending dakwah to regions vulnerable to non-Muslim predication was consistent with this consciously political vision of religious education. Among other things, it also meant that the DDII chose (and still today chooses) to work in regions where it goes head to head with Christian missionaries. ${ }^{26}$ Though traditionalist and modernist Muslims alike were disturbed in the 1960 s by the scale of Christian missionizing, it is the DDII more than any other organization that has brought Christian activities into the media spotlight, condemning them again and again in the harshest of terms. DDII ire is fueled by their belief that conversion undermines prospects for a more thorough Islamization of Indonesian politics. (An Islamization that, unlike the 1950s' Masyumi, the DDII insists is not the same as the establishment of an Islamic State, a demand that would run afoul of New Order policies). Equally important, their ire reflects their conviction that in the late 1960 s and 1970s some national leaders encouraged diversion from Islam with the express intent of weakening mass support for political Islam. Muslims of more moderate persuasion, such as renewalist Muslims (see below) and cosmopolitan members of the metropolitan middle class, often feel uncomfortable with the DDII's fierce diatribes against Kristenisasi (Christianization). Some members of the military have told me that they regard DDII statements as violating government policies on religious pluralism. However, even in the late 1970s, it was already clear that DDII efforts to keep the issue of Christianization in public view were having an impact, influencing new government restrictions on Christian evangelism. ${ }^{27}$

A second difference between the DDII and existing dakwah organizations was that the DDII sought ties with Muslim organizations outside Indonesia and placed greater emphasis on internationalist issues in its dakwah. This internationalist orientation has long been characteristic of Masyumi leaders, but it has become especially pronounced under the DDII. In part this reflects the fact that the DDII became operational in the

\footnotetext{
${ }^{26}$ Indeed, one of the most significant changes in dakwah promoted by the DDII in recent years has been its establishment of predication programs in regions from which Muslim preachers have historically absented themselves. For example, in 1990 the DDII sent preachers into the Tengger highlands in East Java and sponsored the construction of a mosque. The highlands are a predominantly Hindu region where I had done research in the late 1970s and 1985. According to the DDII preachers I interviewed in 1991, ABRI officials in Surabaya had been furious upon learning of this initiative and sought to have the Muslim missionaries expelled on the grounds that the Tengger highlands is officially Hindu. However, in a move reflecting the efforts of higher ranking officials to improve relations with Muslims, their protests were ignored. Similarly, in 1995 and 1996, the DDII began a predication campaign in Nusatenggara Timor, a portion of eastern Indonesia regarded by some Christians as historically Christian and also off-limits, therefore, to Muslim predication. Christian leaders with whom I spoke were upset by this action, regarding it as a violation of government religious policy; DDII officials counter that there is a Muslim population in the region and they have religious rights too. Finally, since 1995, preachers (some DDIIlinked, some independent) have begun work in the Yogyakarta region in villages where Christian conversion occurred after 1965-1966. They are determined to check any further Christian advance, and, if possible, reverse what has already occurred.

27 On the restrictions imposed on Christian Missions in 1978-1979, see M. Bambang Pranowo, "Which Islam and Which Pancasila? Islam and the State in Indonesia: A Comment," in Arief Budiman, ed., State and Society in Indonesia (Clayton [Australia]: Monash Papers on Southeast Asia, No. 22, Centre of Southeast Asian Studies, Monash University, 1990), p. 493. For a discussion of the far-reaching impact of this and other government policies on Christian-Muslim relations in rural Java, see Hyung-Jun Kim, "Reformist Muslims in a Yogyakarta Village," PhD Dissertation, Department of Anthropology, Australian National University, Canberra, 1996.
} 
aftermath of the 1967 Arab-Israeli war and just prior to the oil boom of 1973. Both developments led to an increase in international assistance from Muslim countries, especially from theologically conservative agencies in Saudi Arabia, Kuwait, Pakistan, and Egypt. The DDII has established institutional and educational ties with organizations in all of these countries, and its media organ, Media Dakwah, features commentaries on social and intellectual developments in these countries as well. In this and other ways, Media Dakwah serves as a broker for Middle Eastern Muslim ideas, including harsh critiques of secularism, exposés of alleged Zionist conspiracies, and conservative writings on the role of women in Islam. Indonesian translations of foreign writings of this sort are a notable feature of Islamic publishing under the New Order, in striking contrast to the relative paucity of Middle Eastern political literature prior to $1966 .{ }^{28}$

From the DDII's perspective, the conjuncture of these developments-the timing of its own founding and the growing commitment of Middle Eastern agencies to international assistance-was serendipitous. In the 1970s and 1980s, DDII officials were unhappy with the content of instruction in Indonesian religious schools. Though they welcomed the government's policy mandating religious instruction from grade school to university, they were worried by what they regarded as a liberal bias in the system of Islamic Teacher Training Colleges (IAIN) and, to a less consistent degree, in the Department of Religion as a whole. On several occasions in recent years, DDII officials have remarked to me that they regretted that the government in the 1980 s sent so many promising young scholars to universities in the United States and Western Europe rather than the Middle East, even for advanced training in Islamic Studies. Their suspicions seemed confirmed when some among those young scholars returned home preaching variants of Fazlurian neomodernism and Mu'tazilah rationalismtolerant, pluralistic schools of Islamic interpretation to which theological conservatives object. Even worse from the perspective of the DDII, some of these individuals went on to receive important appointments in the Department of Religion. ${ }^{29}$

In the face of these developments, the DDII sought to take advantage of Masyumi's internationalist reputation and solicit scholarships for study at more conservative centers of learning in the Middle East; they have also received funds for domestic educational programs. Through initiatives like this, the DDII has sent hundreds of students to centers of learning in the Middle East. In so doing, the organization has helped to maintain a cadre of intellectuals committed to an internationalist, and decidedly anti-liberal, version of reformist Islam, one closer in its idioms and spirit to the Middle Eastern Islamic brotherhoods.

\footnotetext{
28 See Jeroen Peeters, "Prophets and Profits: The Internal Structure of the Islamic Book Industry in Indonesia." Paper presented at the conference on "Mass Media and the Transformation of Islamic Discourse," International Institute for Asian Studies, Leiden, March 24, 1997.

29 A regular focus of DDII criticism, the most distinguished spokesperson for a moderately Mu tazilah rationalism has been Harun Nasution, former rector of the State Institute for Islamic Studies of Syarif Hidayatullah, Jakarta. See Saiful Muzani, "Mu'tazilah Theology and the Modernization of the Indonesian Muslim Community: Intellectual Porțrait of Harun Nasution," in Studia Islamika 1,1 (1994): 91-131.
} 


\section{The Politics of Media}

No where is the DDII's political and internationalist consciousness more apparent than in its official publication, Media Dakwah. ${ }^{30}$ Originally Media Dakwah was not a monthly magazine, as it is today, but an intermittent series of stenciled offprints produced for limited distribution among DDII preachers and supporters. During its first years, the publication was used to circulate speeches and policy statements from Mohammad Natsir and other DDII leaders. Media Dakwah was prohibited from circulating materials to the general public because it lacked the permits required for mass distribution. Weakened by the ban on Masyumi and barred from mainstream media, the DDII relied on these inexpensive offprints for its ideological lifeblood. The dissemination of its materials was limited, however, to the predominantly urban network of activists, preachers, and lower-middle class business people on which the DDII was based.

The DDII's media problems took a turn for the worse in 1974. In January of that year, there were street battles in the capital on the occasion of a visit by the Japanese prime minister to the capital. The visit came after several months of press and public debate on foreign investment, and allegations of illegal payments from Japanese investors to high-ranking government officials. Later reports on this protest, known today as the "Malari" Incident, suggest that high-ranking members of the military unhappy with the government's economic policies advised the protesters, and may have provided logistical support. ${ }^{31}$ However, official accounts of the incident placed full blame for the violence on what were claimed to be underground elements of Masyumi and the PSI. Even worse as far as DDII Muslims were concerned, the government took advantage of the incident to crack down on the national press, banning a number of newspapers, including Harian Abadi, a daily linked to the former Masyumi. No Muslim daily ever emerged to take the place of Harian Abadi as a national voice for Masyumi Muslims.

Today reporters and staff at Media Dakwah insist that this crack-down was all part of a deliberate campaign against the Muslim media and, in particular, Masyumi supporters. This view is shared even by Muslims otherwise unsympathetic to Media Dakwah, though these commentators add that activists of a secular democratic persuasion suffered as well. These critics point their finger at then-security chief Ali Moertopo, who was known to work closely with advisors from the Center for Strategic and International Studies (CSIS), a think-tank supported by well-connected SinoIndonesians and regarded by most Masyumi-inclined Muslims as hostile to their interests. ${ }^{32}$ Whatever the precise course of events, it is clear that, after the banning of Harian Abadi, the Muslim community had no independent mass-circulation daily.

\footnotetext{
${ }^{30}$ What follows is based on interviews with Anwar Harjono (DDII head), June 14, 1995; Lukman Hakiem and Aru Syeif Asad (Media Dakwah reporters), January 7, 1977; Natsir Zubaidi, January 10, 1997; and general interviews with Muslim intellectuals, as well as general reading in Media Dakwah.

31 See John Bresnan's summary account of Malari, in Managing Indonesia The Modern Political Economy (New York: Columbia University Press, 1993), pp. 135-63.

32 On the CSIS, see David Jenkins, Suharto and His Generals: Indonesian Military Politics, 1975-1983 (Ithaca: Cornell Modern Indonesia Project, 1984), pp. 20-32.
} 
Making the DDII's marginalization all the more bitter was the fact that the mid-tolate-1970s were years of sustained media expansion, with increasing sales of newspapers and newsweeklies to a small but growing urban middle class. Remarkably, some of the most successful print media to flourish at this time were either nonconfessional or Christian-owned. The influential Tempo, Indonesia's most widely respected newsweekly (banned by the government in 1994), is illustrative of these developments. Tempo was owned and operated by a predominantly MuslimIndonesian staff. But its editorial line was unabashedly independent and nonconfessional, consistent with the brightly cosmopolitan and pluralist tastes of its staff and elite readership. During these same years, the Catholic owned KompasGramedia group also began its ascent to a position of unquestioned dominance in the newsprint and publishing industry. Today this media group dominates the Indonesian publishing industry, owning all or part of some twenty-three magazines and six newspapers, as well as Indonesia's largest publishing house. This is a remarkable achievement for a Catholic-owned conglomerate in a majority-Muslim nation, and a source of pride for some Indonesians, who view it as evidence of their country's religious tolerance. Against the memory of their own marginalization, however, DDII Muslims view Kompas-Gramedia's success with deep resentment, regarding the conglomerate's rise as one more sign of a secularist conspiracy against Muslim media. 33

Editors associated with Tempo and Kompas insist that their publishing success was the result not of government engineering, but of their own skill at responding to the changing tastes of the emerging middle class. ${ }^{34}$ There can be little doubt that these publishers have demonstrated a genius for combining quality reporting with brilliant marketing. The best of their media easily match the finest American mass-publications for their seriousness and breadth of coverage. (Though the media group of which Kompas is part also publishes sensationalist tabloids.) In their editors' view, one additional key to their success has been their decision to downplay religious affiliation and invite gifted Muslim liberals to write for their publications. Not surprisingly, however, DDII authors and other anti-liberals are rarely among those invited.

Though DDII reporters and activists place most of the blame for their marginalization on anti-Masyumi figures in government, others acknowledge that there were commercial reasons for their press difficulties as well. In January 1997, a prominent reporter who once wrote for Media Dakwah and now works in an important government office told me that the greatest obstacle to the success of Islamic newspapers today is no longer government policy but the fact that advertisers shy

${ }^{33}$ On the rise of media conglomerates under the New Order, see David T. Hill's excellent, The Press in New Order Indonesia (Nedlands [Australia]: Asia Paper 4, University of Western Australia Press, 1994), pp. 81110. A detailed presentation of Media Dakwah views on the Catholic-owned Kompas-Gramedia group is presented in the magazine's report on the Monitor affair. In that incident, the most commercially successful of the group's editors was tried and imprisoned for having allowed his magazine to publish a readers poll in which the Prophet Muhammad was ranked low among public figures popular in Indonesia. See "Membedah Jantung Monitor" (To Operate on the Heart of Monitor), Media Dakwah (December 1990): 25-30.

34 Interview with Kompas Associate Editor S. T. Soelarto, January 11, 1997, and former Tempo reporters, January 1997 and June 1995. 
away from the Islamic press. Like other Media Dakwah associates, he feels that security officials sought to muzzle the Islamic press in the 1970s and early 1980s. However, since the late 1980s, he says, the door has again opened for Islamic media. However, fiscal requirements still present serious hurdles to any such effort. Among other things, he claimed, the Department of Information requires a large payment $(\$ 140,000$, he asserted) from anyone requesting a mass circulation (SIUPP) permit. It has only been since the late-1980s that open expression of Islamic piety has become fashionable among members of the Indonesian business and professional class. And it has only been since this period that a few advertisers have been willing to invest funds in Islamic weeklies. However, the majority of large Indonesian businesses remain SinoIndonesian, and many are still reluctant to support Muslim publications.

In the face of all these obstacles, and because after 1974 Masyumi and the DDII lacked a national newspaper, the heretofore limited-purpose Media Dakwah assumed a heavier media burden in the late 1970s. In 1976, under the leadership of the respected (and, among DDII figures, politically moderate) leader Muhammad Roem, the publication changed its format from an intermittent offprint to a monthly newsmagazine of DDII affairs. Still published on inexpensive newsprint, it evolved over the next four years into its present newsmagazine format, which includes newsprint-quality photos and occasional glossy inserts. Media Dakwah's format was also standardized at this time. It was divided into sections, with a primary section on national news, especially as relates to the Muslim community; another on news from around the Muslim world; a multi-page feature report on some aspect of Indonesian politics; and a few columns and regular features. Feature sections include a full-page verse from the Qur'an, always placed at the front of the magazine; an introductory essay by the DDII head (Anwar Harjono at the time of this writing), usually relating some issue of timely importance to a lesson from the Qur'an; commentaries on Qur'anic interpretation; readers' letters; and, very important, a selection of short reports on dakwah activities from around the country. Though not monthly features, fierce exposés of "Christianization" and biting analyses of moral decline are among the topics most consistently featured in news reports.

Like Muslim media in many parts of the world, Media Dakwah blends moral and religious language directly into its reporting, so that reports on current events invariably return to basic themes from the Qur'an and Islamic history. What distinguishes the magazine among Indonesian Muslim publications is that it presents its appeals in a language that is accessible, philosophically unnuanced, and virulently uncompromising. ${ }^{35}$ Stylistically speaking, the language of Media Dakwah is what might be called militantly middle-browist. Though the magazine does publish articles of a

35 These traits were also characteristic of Persis publications during the 1930s, some of which were authored by Mohammad Natsir. Describing the style of writing in that organization's publications, Howard Federspiel observes, "Clarity was achieved by simple sentences, by defining all religious terms used in the discussion, and by avoiding time-consuming lateral problems." Later in the book, Federspiel adds tellingly that, "Persis writing ... offered no quarter and accepted no compromise, but demanded complete submission. . . A genuine Islamic sense of catholicity, of acceptance of disagreement, was lacking among Persis ulama, nor could they envisage a society where the opposition would have the right to disagree for all time. There was, at best, tolerance for only a limited period, since Persis members were convinced that finally all other viewpoints would inevitably conform with their own. This was Islam as ideology rather than religion." See Federspiel, Persatuan Islam, pp. 24, 192. 
serious and specialized nature, the editors encourage writers to keep their prose clear, unembellished, and focused on essentials. Muslim critics of the magazine often refer to its writing as "dry" (kering) and "harsh" (keras), and dismiss it as lowbrow and inflammatory. The magazine has none of the introspective, reflexively critical essays regularly featured, for example, in Ulumul Qur'an, Indonesia's most respected liberal journal (of a loosely neomodernist persuasion). Also absent are the latter journal's wide-ranging and engagingly pluralistic dialogues on non-Islamic religion, Western and Islamic philosophy, feminism, the idea of the Islamic state, and human rightssymposia that have earned Ulumul Qur'an a reputation as one of the most courageously experimental journals in the Muslim world.

Media Dakwah has one other distinctive trait. Unlike the two publications associated with the Association of Indonesian Islamic Intellectuals (ICMI), Republika and Ummat, the magazine makes no attempt to represent the broad range of opinion within the Muslim community as a whole. Alternately ignoring or condemning its Muslim rivals, the magazine presents a unitary and totalizing ideological face. Those deviating too much from a proper Islamic line are portrayed as hypocrites and unbelievers. Fearing pluralism only promotes error, the magazine's editorials are infused with a singleminded ideological fervor that, more than any other print medium in contemporary Indonesia, harks back to the politicized journalism of the late Soekarno era. Throughout all, Media Dakwah's message is adamantly anti-humanist and anti-liberal. Disdainful of speculative philosophy and the religious ecumenicism advocated by some Muslim writers, it emphasizes the uncompromising truth of Islam, Islam's superiority to all other religions, and the threats posed to Muslims in a world dominated by anti-Islamic powers.

Media Dakwah also engages in none of the reporting on film stars and media celebrities found in the more mainstream Muslim media, such as Republika or the now popular Muslim weekly Ummat. Celebrity-reporting in the latter publications has been a consistent source of irritation to DDII officials, who feel that it exacerbates the moral confusion rampant in Indonesian society.

Editors at Republika and Ummat counter these criticisms by emphasizing that their publications are intended not just for political stalwarts or the deeply pious, but for individuals who are still uncertain in their faith and uncomfortable with moral stridency. These editors see their mission in Indonesian society in terms quite different from those of Media Dakwah. In a country still haunted by memories of religious trauma, they say, their charge is to reassure citizens that Islam is modern, tolerant, and in tune with modern concerns. As one of Republika's editors observed in January 1997, "The people at Media Dakwah believe that if something is not approved in the Qur'an or Sunnah it is forbidden. But why should this be so? God made us with minds to inquire and explore. We feel that if something is not explicitly forbidden then it is acceptable to explore it." Thus Republika and Ummat feature regular stories on the arts, television, literature, and fashion trends of interest to the middle- and upper-middle class Muslims who comprise their readership.

At one level, Media Dakwah journalists are well aware that they write for a different reader than magazines like Ummat. When in January of 1997 I asked Lukman Hakiem, probably the most gifted of Media Dakwah's writers (and someone charged with writing some of the magazine's most mordant editorials), whether the magazine felt 
threatened by the appearance of such new Muslim newsweeklies as Ummat, he surprised me with his answer:

No, I'm not worried. We're not really in competition with magazines like that. Our readership is different. Ummat is for the urban middle class and above. We [at Media Dakwah] focus more on "semi-urban" [he uses the English term] Muslims. Many of our readers are Muslim preachers and teachers in kampung and semiurban areas of Indonesia.

What surprised me about this answer was that it appealed, not to high-flying ideological principles, but to a level-headed sociological assessment of market segments. Based on my own samples of readers in Jakarta and East Java, Lukman's observation is quite accurate. The typical Media Dakwah reader resides in or just outside a city, comes from the ranks of the educated lower-middle class or working poor, and has developed an interest in the magazine as a result of a personal identification with Masyumi or participation in DDII predication. Though Media Dakwah has some affluent and well-educated readers, including some from the ranks of student activists, its average reader is from a lower educational and income background than the readers of Ummat or the theologically liberal Ulumul Qur'an. The activist and lowerclass background of much of Media Dakwah's readership works to reinforce its editors' unease with the fashionable concerns of the middle- and upper-middle class.

There are other, equally practical reasons for Media Dakwah's reporting emphasis. Under the terms of Indonesia's strict press licensing regulations, the magazine does not qualify for a "general publishing license" or SIUPP. ${ }^{36}$ It controls only a Surat Tanda Terdaftar (STT), or "Letter of Registration." While a STT permit is inexpensive and easier to obtain, the lack of a SIUPP severely limits a publication's access to the reading public. Some of the restrictions appear petty: a magazine with an STT, for example, cannot refer to its chief manager as an "editor" or its journalists as "reporters." More seriously, a magazine with an STT is not allowed to distribute its product for general sale, but must confine its circulation to "limited circles," such as the members of an organization. Though in recent years Media Dakwah has been allowed to distribute to some bookstores and kiosks, it is still not widely available. Similarly, without a SIUPP, only 10 percent of a publication's pages can be dedicated to advertisements, a restriction that limits a publication's ability to generate revenues for expansion.

Despite these hurdles, Media Dakwah has managed to increase its readership and consolidate its operations, especially since the Islamic revival of the late 1980s and the relaxation of tensions with the government. Today, a typical press run is a respectable sixteen to eighteen thousand copies, with especially popular issues (such as the January 1997 story criticizing Republika) selling as many as twenty-five thousand. Equally important, since 1991 the magazine has become financially self-sustaining, no longer requiring subsidies from the DDII. (Indirectly, however, it still receives building subsidies since it is housed at the headquarters of the DDII on Jl. Kramat Raya 45 in central Jakarta, in what used to be Masyumi's national headquarters.) It has a full-time editorial staff of five reporters and a business team of another five. It out-sources its

\footnotetext{
36. Before 1982, the SIUPP was known as a SIT, Surat Izin Terbit or "Permit to Publish." On the regulations surrounding SIUPP ownership, see Hill, The Press, pp. 47-51.
} 
printing. The magazine also relies on a network of freelance journalists, paid on a perarticle basis.

Despite Media Dakwah's success in establishing a niche for itself in the Muslim reading public, its staff members speak bitterly of the still-limited reach of Muslim media in Indonesia. They point out that, of Indonesia's many Muslim organizations, only one, the mainstream Muhammadiyah, controls a general publishing permit (SIUPP). ${ }^{37}$ They deeply resent that some of the largest publishing groups in Indonesia are Christian-owned, and are convinced that this results in an anti-Islamic bias in reporting.

For all these reasons, Media Dakwah and the DDII leadership welcomed the news that, in January of 1991, a new Muslim daily, Republika, was to be launched. They knew that the newspaper was to be the official organ of ICMI, the Association of Indonesian Islamic Intellectuals. They were also aware of ideological tensions within that government-sponsored organization. However, from its start, Republika was officially identified as a publication that would serve the interests of the entire Muslim community. In an effort to underscore that relationship, the foundation that manages Republika, the Yayasan Abdi Bangsa, sold shares in the paper to the whole Muslim community. ${ }^{38}$ In a political context as unsettled as late New Order Indonesia, however, Republika's pledge to represent the entire ummat-and, by implication, to respond to the concerns of the DDII-would prove a difficult charge indeed.

\section{A Clash of Cultures}

Against this historical background, we can begin to understand the disagreement that pitted Media Dakwah supporters against the Republika staff. Two demonstrations by the DDII-led alliance illustrate some of these tensions.

The first incident took place on April 17, 1995. The immediate provocation for the action was Republika's publication of a special "Friday Report," about which I will say more below. The protesters framed their grievances, however, in a way that highlighted broader differences of philosophy and political vision. For example, the protesters' letter of concern emphasized that, because a significant portion of Republika's operating capital had been accumulated through the sale of stock shares to the broader Muslim community, the newspaper "represents a strategic asset of the Islamic community" and, therefore, "cannot be freed from its responsibility to the entire Islamic community (ummat)." The statement went on to list what it described as "oddities" (keanehan) in the newspaper's coverage of religious and national issues. These included the newspaper's reporting on art performances "that are very unIslamic"; its periodic stories on Shi'i social and political thought (this in a country, one of the demonstrators commented, ${ }^{39}$ where there is no significant Shi'i population); and,

37 Muhammadhiyah has two SIUPP, one for its general magazine and the other for its women's magazine. Neither has achieved a mass-circulation standing.

38 See Hill, The Press, p. 128.

39 Interviews with protest leaders and Republika staff were conducted between December 29, 1996, and January 12, 1997. I had also interviewed protagonists from both sides of this conflict during June-July 1995, and during July of 1993. It is a well-known secret that one of Republika's editors has a sympathetic interest in Shi'i social and political ideas; the Media Dakwah criticism was clearly directed at this man. 
most generally, the newspaper's "tendency to show a cosmopolitan attitude, placing anything and everything in the newspaper without bothering to ask whether that news would have a positive or negative impact on the Muslim community" (emphasis added). 40

The last statement was illustrative of a deeper difference between Republika and Media Dakwah. As noted above, Media Dakwah emerged in a context of political trauma, haunted by the imprisonment of Masyumi leaders, the suppression of Masyumi's newspaper, and the Masyumi community's political marginalization. ${ }^{41}$ Under these circumstances, the DDII survived by shifting away from the give-and-take of public politics, from which it was in any case barred, to an austere program of religious predication and grass-roots struggle, especially among the disenfranchised of urban and semi-urban Indonesia. The strategy, again, was that described by Mohammad Natsir: to engage and maintain the little electrical generator hidden behind and beneath the house.

Inevitably, the deployment of this strategy had an impact on the public vision of the DDII. In the early 1950s, when it was seen as one of Indonesia's most respected and honest political parties, Masyumi was a complex and evolving alliance between, on one hand, Muslim constitutionalists, committed to a procedural democracy and the rule of law (grounded, of course, on Islamic ethical principles), and, to borrow Marshall Hodgson's phrase, "shariah-minded" Islamists, more concerned with the purity of the Islamic message than in experimenting with constitutional politics. As Allan A. Samson observed in his 1972 dissertation, "Islam and Politics in Indonesia," 42 the events of the late Soekarno-era and early New Order weakened the influence of constitutionalists in the organizations that survived Masyumi's demise. In the eyes of their conservative rivals, the proceduralists' commitment to democratic institutions had failed to produce worthwhile returns. Samson interpreted the subsequent hardening of attitudes among ex-Masyumi supporters as the result of a shift in the community's center-of-power from democratic proceduralists to shariah-minded Islamists. Muslim intellectuals in Indonesia with whom I have spoken don't disagree

\footnotetext{
40 The demonstrators' letter of protest and a longer cover story on anti-Republika grievances were published simultaneously in Media Dakwah. See the "Special Report" (Laporan Khusus), "Republika Menentang Arus Umat?" (Republika Opposes the Muslim Community's Current?), Media Dakwah, No. 271 (January 1997): 16-21.

41 Mention was made earlier of the so-called Malari incident of January 1974, blamed in official statements on Masyumi and socialist leaders. However, there were numerous incidents of force against Masyumi and associated reformists in later years. Perhaps the most notorious occurred in the aftermath of the Tanjung Priok violence of late 1984, in which dozens of Muslim protestors (including preachers with spiritual ties to the DDII) were killed during a confrontation with authorities. The incident was followed by several months of arson and bombings, which prosecutors sought to link to opponents of the New Order. Among those subsequently tried and convicted was a charismatic preacher well-liked in DDII circles, A.M. Fatwa. Fatwa was a decent, moderate man who had worked for several years as an advisor to the Jakarta governor Ali Sadikin; his imprisonment was seen by many observers as a none-to-subtle warning to the DDII leadership. Conversely, many Indonesians saw Fatwa's early release in 1991 as an indication of the government's desire to right its relationship with the Muslim community in general, and the DDII in particular. On the circumstances of Fatwa's imprisonment, see n.a., Indonesian Muslims on Trial (London: TAPOL, 1987).

42 Allan Arnold Samson, "Islam and Politics in Indonesia," PhD Dissertation, Department of Political Science, University of California, Berkeley, 1972.
} 
with this analysis, but add, I believe correctly, that the change wasn't just a matter of a shift in the neo-Masyumi community's internal balance of power It also represented an effort on the part of a leadership stripped of its organization-and thereby freed of the obligation to engage in the give-and-take of compromise-to assert what it viewed as most essential in its religio-political project. If all else were lost, if they had to abandon all hope of building an Islamic democracy, there could still be no compromise on these principles. National and international circumstances converged, however, to insure that the interpretation of just what those principles were would take a notably more conservative tack than had characterized Masyumi thought a few years earlier. Political marginalization reinforced ideological essentialization.

There were two especially significant influences on the DDII's evolution, the first international, the second domestic. As noted above, Masyumi's leadership had always been committed to an internationalist understanding of Islam. Its news media had devoted more attention to the larger Muslim world than other Indonesian Muslim media. Yet the world to which Masyumi and the DDII were linked underwent profound changes in the 1960s and the 1970s. One aspect of this change was a hardening of attitudes in international reformist circles toward the United States. Unlike the European powers, the United States had not had a colonial presence in the Muslim world, and reformists in Indonesia and elsewhere had earlier had a neutral or even sympathetic regard for American democracy. Over the years since Masyumi's abolition and the DDII's marginalization, however, the image of the United States in the Muslim world underwent a profound change. After the 1967 Arab-Israeli war, the United States came to be identified with the bitter and humiliating occupation of Muslim lands. At the same time, the image of the United States disseminated in American popular media changed. To put the matter a bit simplistically, if before the United States was portrayed as the land of cowboys and scientists, both of whom excited a grudging admiration, by the late 1970s these icons had been displaced by troubling images of pornography, violence, drugs, and, in general, moral permissiveness. Complicating the matter in Indonesia was the fact that the 1980s saw the near-total collapse of the domestic film industry, and its replacement with American (and other foreign) action films and sexual dramas. Less visible but equally dramatic has been the illegal but widespread importation of European and American pornography, an event that has made hard-core sadomasochistic pornography available even in remote corners of the archipelago. These and other events-the expansion of tourism, alcohol and drug abuse, AIDs, and the growth of the Southeast Asian sex industry-left ordinary Muslims deeply confused about the moral values for which the United States stood. Some became convinced that the greatest threat from the West was less directly political than it was a pernicious subversion of popular morality.

The second influence on Masyumi-DDII's evolution, a domestic one, had to do with the organization's social and class base. In the 1950s, Masyumi had a brightly urban orientation, one consistent with the upbeat middle-class profile of its leadership and economic donors. However, for reasons too complex to detail here, the 1950s and 1960s laid waste to the wealth of the Muslim merchants and small-scale industrialists who had provided the funds on which Masyumi depended. The economic collapse of 
these "old santri" only added to the DDII's difficulties in maintaining a social base. ${ }^{43}$ As we have seen, the organization gradually moved down market in its programs and appeals. Though it continued to look to old santri for much of its financial support, the continuing decline of the santri business class forced the DDII to turn to the poor and lower-middle-class of urban Indonesia for its support. By contrast, the "new santri" middle class that began to emerge in the late 1990s was concentrated not in independent enterprise, but in domains such as state education, bureaucracy, and government-dependent business. Though many in the new santri middle class were drawn to the Islamic revival, they were wary of articulating their religious convictions in terms that might jeopardize their ties with government.

Herein lies an additional clue to the DDII's objections to Republika's press coverage. Hardened by political persecution, driven to emphasize bare-boned essentials, and pushed toward a poorer and less educated social base, the DDII came to emphasize not merely the shariah-mindedness of ex-Masyumi conservatives, but the strict, ungarnished, and anticosmopolitan Islamism of the urban poor and lumpen-middle class.

This social pilgrimage differed greatly from that through which the Republika staff and their readers have passed. Republika is the media offspring of the Association of Indonesian Muslim Intellectuals or ICMI. As I have described elsewhere, ${ }^{44}$ ICMI's creation was the result of a complex convergence of social forces. Among them were the rapid growth of an educated and affluent new middle class; an Islamic revival of historically unprecedented proportions; and, in the late 1980s, President Soeharto's interest in courting a new base of support beyond that of the armed forces. ICMI's internal organization has expressed these ambiguous influences. On one hand, its leadership is dominated by government officials loyal to the Minister of Technology, B. J. Habibie, one of the president's closest advisors. Their charge was to win the support of non-governmental Muslims, while insuring that rank and file members did not overstep the bounds of what was in fact a highly-circumscribed "opening."

At the same time, however, ICMI has provided an institutional umbrella that allows non-governmental Muslims to sponsor activities and debates unimaginable a few years earlier. In its first months, some Western commentators dismissed ICMI as no more than an instrument of presidential power. ICMI would not have come into existence, of course, had the president not seen its establishment as in his interest. In addition, it is clear that the president's willingness to support the organization was enhanced by his confidence that Minister Habibie could control independent-minded

43 On the politics and economics of the Muslim middle class, see Aswab Mahasin, "The Santri Middle Class: An Insider's View," in Richard Tanter and Kenneth Young, eds., The Politics of Middle Class Indonesia (Clayton [Australia]: Centre of Southeast Asian Studies, Monash University, 1990), pp. 138-144; and Robert W. Hefner, "Markets and Justice for Muslim Indonesians," in Hefner, ed., Market Cultures: Society and Morality in the New Asian Capitalisms (Boulder: Westview, 1998), pp. 237-72. On the changing nature of the Indonesian middle class generally, see Howard W. Dick, "The Rise of a Middle Class and the Changing Concept of Equity in Indonesia-An Interpretation," Indonesia 39 (1985): 71-92.

44. Robert W. Hefner, "Islam, Class, and Civil Society: ICMI and the Struggle for the Indonesian Middle Class," Indonesia 56 (October 1993): 1-35. See also M. Syafi'i Anwar's excellent overview of ICMI and religious politics, Pemikiran dan Aksi Islam Indonesia: Sebuah Kajian Politik Tentang Cendekiawan Muslim Orde Baru (The Thought and Action of Indonesian Islam: A Political Analysis of Muslim Intellectuals Under the New Order) (Jakarta: Paramadina, 1995). 
members of the organization. But a minority within ICMI has continued to struggle to carve out a sphere for independent action. Quietly but persistently, they have tried to promote what they regard as democratic interests, sponsoring colloquia on human rights, publishing articles on the rule of law, and encouraging public discussions of Islam, pluralism, and social justice.

Over the years since the organization's founding, the space for independent activity within ICMI has diminished, and many Muslim political reformers who once supported the organization have grown disillusioned. ${ }^{45}$ The disillusionment has been all the greater inasmuch as many people now believe that the political opening trumpeted in the early 1990s has, at least for the moment, closed. The banning of three of Indonesia's most respected newsweeklies in $1994,{ }^{46}$ the campaign against the Muslim democrat Sri Bintang Pamungkas (a founding member of ICMI) in 1995, and the clumsy ouster of Megawati Soekarnoputri in 1996 shocked those who hoped that the New Order was gradually relaxing its hold on public life. Corruption scandals in the nation's supreme court, a crackdown on a fledgling independent labor movement, and stricter controls on non-governmental organizations have only added to this growing despair. ${ }^{47}$

Though all this may be true, the fact remains that the government's opening to reformist Islam, however controlled, has given some in the reformist community a platform from which they and their colleagues had long been barred. After an almost twenty-year absence, the government's awarding of a General Publication License (SIUPP) to Republika was welcomed even by those who understood that the newspaper would be subjected to intense political pressures. It has been so pressured, indeed repeatedly. But this has not prevented some Republika reporters from bravely raising questions of political and ethical importance. The best among the Republika staff have walked a tight rope between demonstrations of respect for the government and maintaining the independence required to win readers and demonstrate that Muslims can be principled journalists. These reporters operate in an environment dominated by non-confessional newspapers. The success of these newspapers, Republika journalists have told me, owed much to their ability to demonstrate their independence, reach across religious lines, and address the fashions, controversies, and concerns of middleclass readers.

This competitive environment places Republika in a position entirely different from that of Media Dakwah. Whereas Media Dakwah has a ready-made audience in the ranks of DDII supporters, and whereas most of that audience comes from the urban lower and lower-middle class, Republika reporters rightly recognize that their newspaper will survive only if it can speak clearly and honestly to issues of concern to the Muslim middle- and upper-middle class. Many of these people have only recently begun to

45 A recent illustration of this fact was the "resignation" from ICMI of the outspoken head of the Muhammadiyah, Amien Rais, in February of 1997. He was forced out after raising questions about a number of government policies, including several that concerned the business empires of the first family.

46 See "Three Strikes Against the Press," in The Limits of Openness: Human Rights in Indonesia and East Timor (New York: Human Rights Watch, 1994), pp. 4-20.

${ }^{47}$ An essay that captures brilliantly this loss of political faith among the educated middle class is Goenawan Mohamad's, "Bohong" [Lies], a front-magazine column in Jakarta's outspoken newsweekly, DER 21 (January 4-11, 1997): 10-11. 
take their religious obligations seriously. Given their government and business connections, most are reluctant to do anything that might appear radical or antigovernmental. They are also uncomfortable with an Islam that is, as one Republika editor put it, "only about telling people what not to do." But many among these readers would also like to see a fairer and more transparent political-economic system. In this setting, Republika staff have told me, they believe their newspaper has to demonstrate that it is tolerant, plural, and modern, as well as pious and critical. In other words, the "cosmopolitanism" for which Media Dakwah faults Republika is just that: an effort to show that Islam is not just a matter for villagers and ulama, but a religion that can inspire a social conscience consonant with popular aspirations for openness, pluralism, and informed sophistication.

Of course, it is not just the desire to expand readership that underlies this effort. However much its upper ranks have become packed with government officials, ICMI has always included in its ranks a small but influential number of ethically principled and democratic-minded intellectuals. The most famous of these are, of course, such respected renewalist (pembaruan) intellectuals as Nurcholish Madjid and Dawam Rahardjo. ${ }^{48}$ However, contrary to some Western accounts, the supporters of press freedom and Islamic pluralism within ICMI include people of more varied theological and political persuasions than renewalists alone. Well known for his commitment to a free press, Bintang Pamungkas, the democratic legislator (and ICMI member) tried and imprisoned by the government for criticizing the president, has never been a neomodernist or theological liberal; on matters of religious principle he is closer to the DDII. Republika's business editor, Haidar Bagir, is well known for his commitment to journalistic integrity and intellectual freedom, a commitment earlier demonstrated in his founding of the Mizan Press, one of the most intellectually sophisticated and pluralistic publishing houses in the Muslim world. But on matters of worship and basic religious principle, Haidar is known to be rather strict or conventional. As these and other examples illustrate, the commitment to press freedom and openness among Republika staff and their supporters is not restricted to people of a theologically liberal persuasion, but is shared by many independent intellectuals. It is important to emphasize this point, because Western and Media Dakwah analyses alike have sometimes implied that support for Republika's independence is limited to a handful of liberal Muslims. In fact, however, the commitment to a spirited and pluralistic journalism is found across a broad spectrum of Muslim observers. From this perspective, the independent-minded wing of Republika and Ummat are stronger than sometimes believed because their interest in pluralism and transparency is shared by a wide array of middle-class Muslims.

Which brings us back to the DDII-led demonstrations against Republika. Though, as the statement that accompanied the April 17 demonstration indicated, the demonstrators were upset by a number of things, their ire had been especially provoked by a story that ran on March 31, 1995 in a special supplement to Republika

48 At the time of Republika's founding, it was widely expected that Dawam Rahardjo would assume the role of editor-in-chief. However, at the last minute he was shunted aside in favor of Parni Hadi, a likeable and pious man, preferred by government officials because of his cordial ties to the then Minister of Information, Harmoko. On neo-modernism geneally, see Greg Barton, "Indonesia's Nurcholish Madjid and Abdurrahman Wahid as Intellectual Ulama: The Meeting of Islamic Traditionalism and Modernism in neo-Modernist Thought," Studia Islamika 4,1 (1997): 29-83. 
known as the "Friday Dialogue." This supplement is devoted to the exploration of new, alternative, or special-interest issues in Islam. The article in question was a twopage reflection on the life and thought of Ahmad Wahib. Wahib was a young, independent-minded student activist killed in a motorcycle accident in 1972. He had been a member of the "Limited Group" discussion circle in Yogyakarta that, in the late 1960s, had engaged in boldly exploratory discussions on the nature of Islam. The group met under the sponsorship of Mukti Ali, a principled modernist intellectual tapped in 1971 to become the Minister of Religion. The Limited Group's discussions were wide-ranging, however, and often touched on controversial issues, such as the youths' dissatisfaction with what they saw as a conservative, ulama-dominated understanding of Islam. ${ }^{49}$

Wahib kept a diary over these years and used it to record his youthful ruminations and frustrations. It seems clear that he had not intended that the diaries should be published, at least not in their original form. However, when he died in a motorcycle accident in 1972, his close friend Djohan Effendi discovered the diary manuscript. In 1982 Effendi arranged to have the diary published by LP3ES, a non-governmental organization and publishing house headed at the time by Dawam Rahardjo, another Wahib friend (and the founder and executive editor of Ulumul Qur'an). Though he was a Madurese from a pious santri family, Wahib's diary abounds with expressions of doubt about the mission of the Prophet, the proper meaning of the Qur'an, and the intellectual integrity of ulama. However, after every one of his introspective crises of faith, Wahib always returns to decisive affirmations of Islam. Nonetheless his statements of angst are so severe that they shocked some of Indonesia's leading ulama, several of whom publicly expressed their "regret" that the book had been published.

The elegization of Wahib infuriated Republika's DDII critics. In a letter of protest circulated at the demonstration, they cited no fewer than thirty-six passages where, they asserted, Wahib had insulted (menhina) Islam, the Qur'an, the Prophet, and God. The offending passages included statements like, "There is no Islamic law, there is only the history of Muhammad" (p. 60); "the Qur'an contains many passages that are no longer used" (p. 38); and "The Qur'an is not identical with Islam." The protesters argued that Wahib, who had lived for a while in a Christian boarding house when a student in Yogyakarta, had been influenced by ideas from "Jews, Christians, philosophers, and [Javanese] mystics." They also argued that Wahib's defamation of Islam was every bit as serious as several well-known cases where the offender had been tried and imprisoned. The clear suggestion was that the junior reporters who had authored Republika's glowing report on Wahib deserved equally severe disciplining.

Republika's editors responded to the demonstration by welcoming the protesters into the front office for a discussion intended to cool passions. However, many of the demonstrators continued to cry, "Allahu Akbar," and the newspaper staff feared violence. Eventually, the newspaper's editors acknowledged that mistakes had been made; that they hadn't understood the depth of opposition to Wahib; and that measures would be taken to insure that no such error would happen again. "This is

49 An English-language overview of Wahib's background and thoughts is presented in A. H. Johns's "An Islamic System or Islamic Values? Nucleus of a Debate in Contemporary Indonesia," in W. Roff, Islam and the Political Economy of Meaning: Comparative Studies of Muslim Discourse (London: Croom Helm, 1987), pp. 254-280. 
our mistake, because we weren't sufficiently careful in selecting articles to be published for that day," said the assistant editor S. Sinansari Ecip. ${ }^{50}$ Though the demonstrators demanded their dismissal, the young reporters responsible for the article were not fired, but moved from the reporting staff to the less visible research department. It did not escape the attention of Republika staff that the demoted reporters were well known not only for their interest in Wahib, but for their sympathy for the democratic ideas of "transformative" Islam as well. ${ }^{51}$

The second DDII demonstration at the Republika office occurred on December 30 , 1996. This time the demonstrators reiterated their earlier criticisms, that Republika is too cosmopolitan, prone to celebrity-mongering, and insensitive to Islamic morality. However, there was also something new to the demonstrators' broadside, and to the story that accompanied the demonstration in the January 1997 edition of Media Dakwah. Copies of the materials the demonstrators viewed as offensive were sent to leading ulama, directors of religious schools, ICMI officers-and senior officers in the Indonesian armed forces. Among the documents were letters from Taufiq Ismail, a respected Muslim poet well known for his ferocious hostility to anything emanating from the political Left, and K. H. A. Kholil Ridwan, an alim with ties to the DDII.

The demonstrators took issue with several Republika stories and actions. They condemned the newspaper for wishing "Selamat Berhari Natal" [A Blessed Christmas] to Indonesia's Christian community. This gesture, they explained, contradicted recent legal pronouncements of the state-sponsored Council of Indonesian Ulama (Majelis Ulama Indonesia) to the effect that to wish someone Holy Christmas was, in effect, to recognize the legitimacy of Christian belief, and was thus forbidden. The demonstrators also expressed anger at Republika's favorable review of Arnold Schwarzenegger's new Christmas comedy entitled (in its Indonesia release) "Jingle All the Way."

There were other points of contention, but the protesters' central grievance concerned the newspaper's coverage of the July 27 attack on the PDI headquarters; the arrest and trial of the leaders of the Partai Rakyat Demokrasi (the People's Democratic Party, or PRD), whom the government at first blamed for the subsequent riots; and an interview the newspaper had run with retired Lieutenant General Soebijatko Prawirasoebrata. General Soebijatko is an associate of retired General Rudini, a friendly critic of the government; among armed-forces retirees, General Soebijatko is recognized as a considered and intelligent voice for moderate political reform.

In a sharply worded attack, the demonstrators' letters denounced Republika as biased and contrary to the interests of Muslims, the nation-and the armed forces. Even Lieutenant General Soebijakto was condemned for presenting "perspectives [that are] very pro-PRD." To direct a charge like the latter against a military retiree as respected as General Soebijakto is, in the Indonesian context, nothing less than

\footnotetext{
50 As quoted in one of the few magazines to run a story on the incident, "Didemo Khalayak Sendiri" [Demonstrated Against by Their Own Public], Sinar (April 22, 1995): 82.

51 Remarkable by the standards of any part of the Muslim world, two of the most influential exponents of transformative Islam are Masdar F. Mas'udi and Moeslim Abdurrahman. Masdar comes from a NU background, Moeslim from Muhammadiyah. For illustrations of their bold ideas, see Moeslim Abdurrahman, Islam Transformatif (Jakarta: Pustaka Firdaus, 1995), and Masdar Mas'udi, Islam dan HakHak Reproduksi Perempuan (Bandung: Mizan, 1997).
} 
shocking. Having condemned the PRD as communist, the demonstrators were by implication saying that, intentionally or not, General Soebijakto was acting like a communist sympathizer. Republika was criticized in similar terms for providing "support to leaders and movements of the left." Particularly offensive in the protesters' eyes were interviews Republika had run with PRD leaders and activists associated with the progressive Indonesian Student Solidarity for Democracy (SMID, Solidaritas Mahasiswa Indonesia untuk Demokrasi).

It is important to remember that Republika's coverage of the July 27 incident and the arrest of the PRD leaders had originally been notably unsympathetic to both the PRD and Megawati supporters. At first the newspaper had gone along with the government prosecutor's line, or, at the very least, had chosen not to question it openly. However, in the days following the incident, as the government identified the PRD as the masterminds of the July 27 riots and as a communist front group, many in Indonesia, including many in the Muslim community and military, began to questions the wisdom of these charges. Through leaks and public comments, it became apparent that a number of figures in the Armed Forces had opposed the attack on the PDI headquarters, fearing it would only tarnish ABRI's image. Eventually, public skepticism toward the government case became so strong that prosecutors changed the charges against the party's leaders. Rather than identifying PRD leaders as masterminds of the July 27 disturbances, they charged them with subversion, "hatred of the government," and opposition to the Pancasila.

This change caused deep embarrassment among the independent-minded staff at Republika, who realized that they had been too uncritical in their earlier reporting of the government's case. Regretting the earlier rush to judgment, Republika's reporters were determined to acknowledge their error and demonstrate that they were capable of fair and objective journalism, even when reporting on the prodemocracy Left or on issues to which some Muslims might object. There was a journalistic principle to be defended, I was told by one such reporter. Thus, in several prominent stories, the newspaper presented the case against the PRD in rich detail, and in a manner which-given government prosecutors' mishandling of the case-led many readers to doubt the credibility of the government charge. A planned series of in-depth reports on the PRD was never completed, however, because after publication of the first such report Republika's editors were bombarded with protests from high-ranking government officials. Overruling their junior reporters, the newspaper's editors apologized in print, announcing that it was unwise to run additional stories while the case against the PRD was pending.

The demonstrators outside the Republika office had no such qualms about the PRD or the government's efforts. Their "Statement of Concern to the (Islamic?) Newspaper Republika" reiterated the government's earlier charges about the PRD, and condemned Republika's nuanced reporting in the sharpest of terms:

Republika's support for movements and intellectuals of the Left has been expressed continuously and repeatedly. ... The bias and support of Republika toward the PRD represents a slandering of the Islamic community's effort to make people aware of the danger of the revival of communism in Indonesia. . . Republika 
clearly also has challenged President Soeharto who has affirmed that the PRD is identical with communism. 52

There is much more to the demonstrators' document and the Media Dakwah special report that accompanied it. The central theme of both statements, however, was that Republika was supporting the communist Left, sowing discord in the Muslim community, and antagonizing heretofore cordial ties with the Indonesian armed forces. The demonstrators concluded their statement with an appeal to the Department of Information (which licenses the press), the governmental Council of Indonesian Ulama (MUI), and ICMI officers to investigate the newspaper's staff. In the meantime, they urged Muslims to cancel their subscriptions, emphasizing, "It is dangerous, if in the name of Islam and supported by the Muslim community, Republika deceives and misleads the Muslim community itself."

\section{Conclusion: The Struggle for a Public Sphere}

Many reporters in the Jakarta community, both in the Muslim and nonconfessional press, were convinced that the DDII campaign against Republika had been engineered by a small, antireform faction in the intelligence services. Rumors had it that those security officials had been angered by Republika efforts to provide balanced reporting on the PRD and the July 27 violence. These sources are quick to point out that the armed forces themselves were far from agreed on the wisdom of the July 27 assault on the PDI. It is no secret that many high-ranking ABRI officers objected to the campaign against Megawati, and feared that her elimination would only increase the chances of the ICMI head, B. J. Habibie, succeeding President Soeharto. Observers who make this argument, claiming the demonstration against Republika was engineered by intelligence officials, take pains to point out that only a small faction in those services was responsible, not security or military officials as a whole.

DDII officials reject such charges as specious slanders designed to split the Muslim community and create tensions between Muslims and the armed forces. Given the highly charged atmosphere in Jakarta in late 1996 and 1997, the possibility that there was indeed such a rumor campaign against the DDII cannot be ruled out. Whatever the truth in this instance, however, the evidence of Media Dakwah's own reporting after the events of July 27 makes clear that, after years of marginalization, the DDII leadership has concluded that it must take full advantage of the thaw in relations with (some in) the government, and to do so means taking a hardline on recent political events. This is a serious gamble, and one that represents a departure from the principled position earlier staked out by Anwar Harjono, the current DDII chairman. As a member of the Petition of 50 during the 1980s and early 1990s, Harjono regularly joined other prominent critics of the government in raising pointed questions about democracy and social justice.

The shift in the DDII's public posture is also one about which some moderate DDII officials continue in private to express concern. Nonetheless, in the months following the July 27 incident, Media Dakwah ran numerous special reports reviewing in detail the threat of communism, the communist roots of the PRD, and Muslims' proud role in the

52 "Pernyataan Sikap Keprihatinan terhadap Surat Kabar (Islam?) Republika," a statement presented to Republika, December 30, 1996. 
extermination of the PKI during 1965-1966. DDII-linked groups have also launched attacks on government critics and human-rights advocates, characterizing human rights as a Western fraud. Finally, and most surprising for some reform-minded Muslims (including some affiliated with the DDII), the magazine has also joined the attack on Sri Bintang Pamungkas, the Muslim legislator imprisoned for criticizing the president and calling for greater democratization. Before 1996, Media Dakwah had portrayed Sri Bintang as a pious Muslim and person of deep political conviction; sometimes the magazine used Sri Bintang's statements to introduce general criticisms of corruption and official policy. ${ }^{53}$ Deliberate or not, in presenting these new positions Media Dakwah has taken a stand noticeably closer to that of anti-reformists in the government.

It is an understatement to say that (asymmetrical) collaboration between civilians and the military is nothing new in Indonesian politics; it has been the bedrock of New Order politics. Given the uncertain outcome of today's elite spats and the decisive role of the military in any future scenario, it is also understandable that civilian reformists and hardliners alike are eager to court military support. As long as the Indonesian military's doctrine of dwifungsi ("dual responsibility," i.e. the military's duty to involve itself in domestic politics as well as defense) remains in place, there is in principle nothing unusual or improper about such contacts. In fact, if the lessons of democratic reform in other parts of the developing world are relevant here, such contacts will have to be expanded if and when there is to be meaningful reform. ${ }^{54}$ However, many people, including leading ABRI officials, believe that when such collaboration is conducted off-stage in a netherworld of secret deals and alliances, it undermines both the armed forces' mission and the prospects for orderly change.

Whether such offstage influences are at work in the current conflict between Republika and its DDII critics cannot be decisively proven. Whether such hidden alliances may also be behind the "anti-Christian" riots that swept Indonesia in 1996 is also unclear. However, many people are convinced there is a link between these two events. It is widely believed that much of the "religious" violence in 1996 and 1997 was organized by shadowy third forces; President Soeharto himself believes this to be the case. Just who those forces are, however, is not something on which there is much agreement. Where there is a broader consensus among political observers is in the belief that tensions among the ruling elite have recently heated up and may well be prompting certain individuals to resort to tactics that, in another time or place, they might have regarded as inappropriate and dangerous.

\footnotetext{
53 See the harsh report on Sri Bintang, for example, in the April 1997 issue of Media Dakwah, "Ulah Bintang dengan Lebaran Politik," pp. 8-10.

${ }^{54}$ A point aptly summarized in a recent overview of the Indonesian military: "The emergence of a truly independent political party in New Order Indonesia will not be possibile without tacit approval from at least a fragment of the Armed Forces. Indeed, the possibility of a civilian politician such as Megawati making a serious run at the Presidency will only be possible if a fraction of the military elite-either active or retired-provides support and a degree of protection." See the Editors, "The Indonesian Military in the Mid-1990s: Political Maneuvering or Structural Change?" Indonesia 63 (April 1997): 105.
} 
As reformers like Adnan Buyung Nasution have long emphasized, 55 offstage dealmaking makes it difficult to advance the cause of openness and accountability in politics and the mass media. If they have indeed played a role in recent events, subterfuge alliances violate the formal rules even of the existing Indonesian political order and make politics vulnerable to big-power plays. They also undermine the efforts of many decent Indonesians attempting to make the press a foundation for public dialogue and accountability.

These then are the issues affecting the struggle for a Muslim press in contemporary Indonesia. They are weighty issues indeed. However much they might wish otherwise, the strategies of the Muslim protagonists in this struggle have not been determined by the timeless values of universal Islam or, as certain western political scientists would have it, unchanging "civilizational" identities. There are here deeply different varieties of political Islam. Their struggle shows all too clearly the constraints of Indonesia's present political system, and hints at the compromises even principled players may have been obliged to make. It is a sign of the times in contemporary Indonesia that there are well-meaning individuals on all sides wondering whether some among their comrades might have struck the wrong deal, and whether it should not have been otherwise.

55 The issue with which I am concerned here, the deleterious impact of offstage intrigues on democracy's possibility, is, of course, the focus of Buyung's own efforts to improve Indonesia's legal system, and of his masterful, The Aspiration for Constitutional Government in Indonesia: A Socio-legal Study of the Indonesian Konstituante 1956-1959 (Jakarta: Pustaka Sinar Harapan, 1992). 
